\title{
Visual Representation of Urban Environment: Microraioni of Riga in Soviet Cinematography
}

\author{
Jānis Matvejs, University of Latvia
}

\begin{abstract}
The aim of this article is to interpret the discourse of residential areas of Riga through the films of the Soviet period and to examine essential changes in residential structure. Specific image of cinematic formal techniques is used in relation to the urban. The results of movie review are compared with changes in the residential development between 1945-1990. $\mathbf{1 2 4}$ movies display that residential areas are frequently portrayed in the Soviet cinema and they form an integral part of the Soviet urban perception.
\end{abstract}

Keywords - Cinema, microraions, panel-block apartment, representation, Riga, the Soviet Period.

\section{INTRODUCTION}

A visual representation is an image that is presented in a particular way to have its own meaning [9]. Cresswell and Dixon contend that films are not mere images of unmediated expressions of the mind, but rather a temporary embodiment of social processes [4]. Cultural geography tends to interpret these images of a city and the processes within it as a cultural landscape. Visual representation of a city creates unique perspectives that allow us to interpret the urban environment and enable us to understand a space, which is culturally created and territorially organized. Moreover, urban visual representation is one of the most important approaches in cultural geography that creates unique perspectives and that allows researchers to explain a city in a way that traditional natural and social sciences are not capable of [14], [25], [26], [28], [29].

Residential complexes are an essential part of cities. This challenges geographers to undertake new research methods by describing the continuously changing city space. Cinema is a specific representation form of residential areas. Regardless of genre, narrative and techniques used, movies always describe a particular period of time [10], therefore are a representation of a city and processes within.

As stated by E. Mazierska, researching socialism movies provides a way that allows us to find gaps and contradictions in the official Soviet history and its cinematic representation by creating an alternative history [16]. The focus of this research is to describe the portrayal of Riga's residential areas in one of the most controversial stages in the history of Latvia - the Soviet period. Even though many studies have reported on the urban development of Riga, there has been very little research on exploring how those residential areas were depicted in the movies of the Soviet period.

\section{Interdisciplinarity of the Subject}

There has always been a connection between cinema and cities, which has influenced human spatial perception. However, only in 1990s has the amount of research, that interprets relations between cinema and city, started growing rapidly [23]. These studies have undergone a crucial shift from distinguishing different geographical categories in movies, for example, journeying to the city, modernist or future cities, to focusing on the link between cinematic visuality and urban imaginary. Cultural geographers have contributed to theorization of the relationship between geographies of modern urbanity and contemporary cinema. Certain scholars affected urban representation that was characteristic to their own period of history. Frederic Jameson and Walter Benjamin contributed to notions that cinema represents a space where city dwellers might pause and make norms of modern urbanity [13]. Likewise, geographers often quoted Jean Baudrillard's conception of city space as 'screenspace' where the border between the real and represented space becomes indistinct [30].

Recently there has been a renewed interest in urban development of the Soviet, which outlines the interaction between political power, financial ability and ingenuity in urban planning processes. This period also embodies the beginning of another phenomenon that was unprecedented for the Latvian society - the rapid development of residential areas or microraions.

Previous research of cities in Soviet cinema tends to analyse individual movies by outlining urban components, social interactions and political effect on urban development. In-depth content analysis is used in the interpretation of movies, likewise studies reveal the following interdisciplinary aspects: movie subject as an explorer of space [21], Soviet residential area as a psychologically modified environment [18], search for national identities in movies of different periods [20], overall description of living space [15].

However, neither of studies provide any descriptive evidence of how the residential areas are visually represented. This position correlates with the tendencies in humanities in general where until 1970s historical studies were widely regarded as more sophisticated than geographical studies [15]. Moreover, geography and studies of urban representation have never been a priority in the Soviet Union. 


\section{Methodology of the Research}

In order to better understand the subject, complex research methodology was developed. The whole research consists of several steps:

1. Analysis of literature - features of residential development and spatial structure of the socialist city were identified. Additional emphasis was placed on the studies of cinematographic approaches used in geography.

2. Content analysis of movies of the Soviet period based on the analytic approach described by A. R. Hazan. et al. [11], in which each movie was divided into 5-minute intervals. The occurrence of microraions in each interval was recorded on a coding sheet. Both actual and implied $m i$ croraion scenes (e.g., city plans or visualizations), the presence of construction tools, prefabricated panels or greenfield sites and audio messages, including conversations and spoken text explaining the visual material, were recorded.

3. Division of Soviet cinematography into a five-stage residential area construction model described by M. Gentile and Ö. Sjöberg [7].

4. Analysis of gathered data and interpretation of conceptual trends was performed.

5. Cartographical method of depicting the displayed points onto a map by applying frequency approach was used.

\section{Complexity of the Soviet Residential Space}

During the inter-war period, the Baltic States introduced independent modern architectural style, thus the new standards in building processes were adapted quickly. The housing program of city administration started in the 1950s with centrally located small apartment blocks arranged in small clusters [7]. Even though initially residents were forced to live in crowded apartment blocks provided to workers by the companies representing the largest industries, the 20th Congress of the Communist Party of the Soviet Union in 1956 set the goal of resolving the housing shortage within 20 years. Each region was imposed to achieve Five-year Plans issued by The State Planning Committee that strongly influenced residential development and created the perception of city as a homogeneous system [3], [5], [8]. Stalin's artificial Soviet skyscrapers in the city centre and housing blocks or kvartaly eventually were replaced with modest apartment buildings in Khrushchevka microraioni built on greenfield sites [5]-[7], [24], [27].

The share of prefabricated parts increased rapidly, however, the hasty process of construction led to the decline of living standards by the end of the Soviet period [8]. In the early 1960s the use of new and more advanced construction materials, for example pressed stone and steel-reinforced concrete, was on the rise. Consequently, brick houses were replaced with large-scale panel constructions [5], [17], [24], [27]. The necessity of combining new production methods with residential typologies and importance to accelerate the building process led to a change in the settlement model [5], [17].
Primarily, residential apartments were located in five-story linear buildings arranged in parallel lines or perpendicular to one another. Clusters of residential buildings particularly were built alongside each other in order to maintain service networks [5]. Subsequently, starting from the mid-1960s, the five-story housing model was replaced with nine to twelve floor residential slabs in many urban outskirts all over the Soviet Union, because of its high development costs [1]. Residential districts were built at the periphery and near forests, waterfronts and arable land in order to satisfy basic human and social needs [3], [8]. This period also advanced social and ethnic segregation due to limited freedom in choosing residence, therefore older persons and locals remained in the poor-quality houses in the central parts of the city while the new generation and immigrants were provided with apartments in microraions [9], [27].

Soviet residential apartment planning was an approach aimed at shaping the society by illustrating Communist lifestyle, unity of society and Party, and social hierarchies [8], [24]. Usage of reinforced concrete panels in on-site construction processes was associated with the idea of progress. In order to advance socio-spatial homogeneity, each residential area was provided with similar services that were accessible to all residents.

IV. URBAN COMPONENTS IN THE Cinematography of the Soviet Period

Urban representation in the Soviet cinematography is a complex phenomenon, mainly because of the fact that the movies primarily are based on literature [16]. Accordingly, the majority of the Soviet movie narrative focuses on heroic characters rather than on the portrayal of urban components. Therefore, place and space has an insignificant role in the Soviet cinematography. Throughout this period, both urban and rural landscape are passive and distracted from character. Moreover, space is represented as perfect and complete, denying the arbitrary representation of cities [23].

Urban components represented in the Soviet cinematography are characterized by their region of origin. In the Baltic States, movies especially depicted historical sites: scenes with ancient components, overview of the city, building facades and enduring restoration of the Old Town [16], [19]. Movies filmed in the Baltic States represented wealthier Western, especially German and Swiss, countries [21] (Fig. 1). Soviet cinematography does not reveal genuine urban space with untidy courtyards, garbage on the streets, marginalized communities or historically controversial objects. Instead, cities are depicted from above or a distance, creating idealized perception of space. Representation of Soviet residential complexes in movies appeared later than in the Western countries [18], [19].

Urban space in the movies of the mid-1940s and during the $1950 \mathrm{~s}$ is represented as utopian and monotonous, continuing Stalin's artificial grand style with enormous buildings and submissive crowds. A great number of movies from this period interpret the heroic scenes of World War II [12]. The intention to maintain 


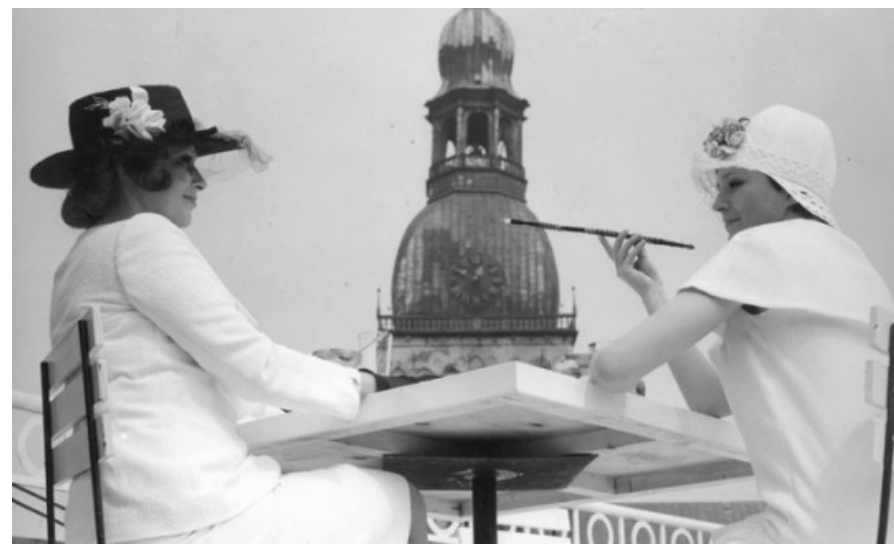

Fig. 1. Representation of Riga as a wealthy 'westernized' Soviet space in movie Ceplis (1972) [31].

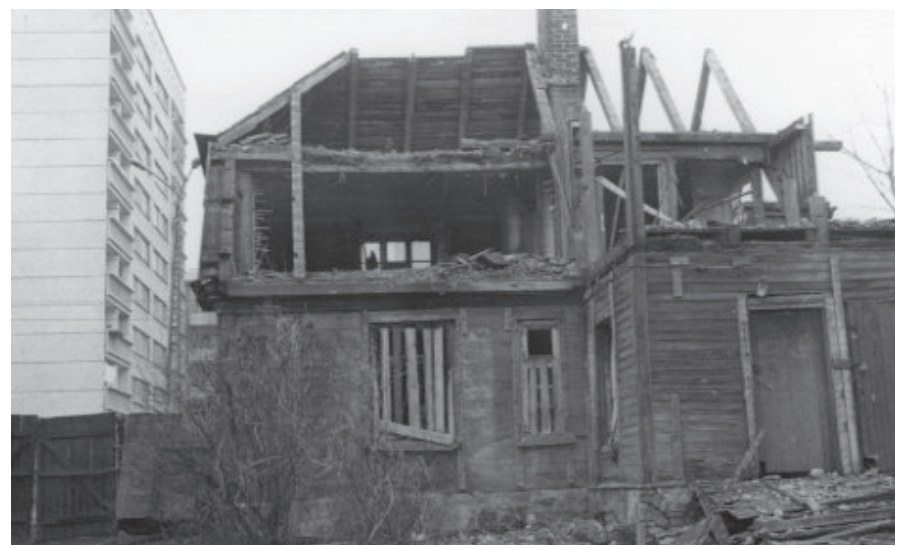

Fig. 3. Representativeness of new architecture contrary to traditional wooden architecture [31].

national identity is illustrated by the activities that are taking place in the countryside [20].

The movies of the 1960s aim to illustrate the city as anti-monumental and spontaneous, for example, July Rain (Ijulskij dožd, M. Huciev, 1967), where the main character's experience is the space and the city is [23]. During the late 1960s and 1970s, cinematography brings harmonious representation of the Soviet city to the end and creates a metaphor of imprisonment and enclosure by confronting historical buildings of the Old Town with modern architecture in the suburbs, as well as creating post-memory border between the nostalgic past and the present [12]. Movies inform about a person's inability to control the space and about the necessity to accept new living conditions [21], e.g. Marriage of Convenience (Małżeństwo z rozsadku, S. Bareja, 1966). Movie characters are glorifying the enormous post-war construction processes of residential buildings, schools and hospitals [15]. During the 1970s, Soviet cities are pictured as calm and quiet, where residents live their own intensive working life [22] (Fig. 2). Contrary to peaceful urban space, an apartment in the movies of mid-1970s turns into a social epicentre where characters feel both secure and despise existing living conditions [15].

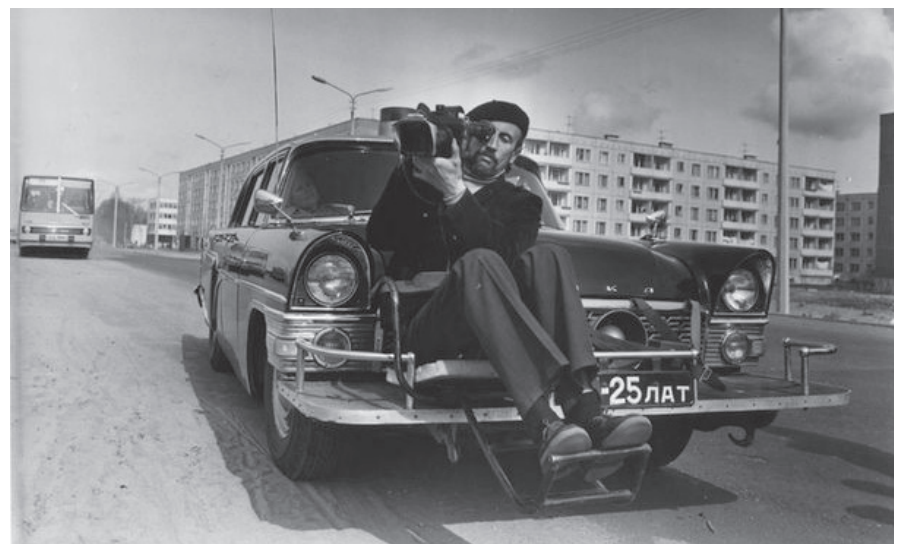

Fig. 2. Cameraman Heinrihs Pilipsons is filming residential area Imanta in movie Šis bīstamās balkona durvis (1976) [31].

Resistance against the existing living standards begun with documentaries [18]. Ecological and welfare anxiety in the area of the Baltic States was strongly altered with the late Soviet nostalgia for the lost freedom resulting from the Soviet political, economic regime and urban modernization [22]. Soviet movies of the 1980s depict city in a manner of a dystopic representation outlining new and overpopulated residential districts, anxiety about the loss of national identity, aimless movement through the city and usage of variety of cinematographic approaches, such as, closeups, static images, silent scenes or associative techniques [21], e.g. in movies: I am not a tourist, I live here (Ma pole turist, ma elan siin; P. Urbla, 1988); Flamingo - The Bird of Fortunate (Õnnelind Flamingo; T. Kask, 1986). Cinematography increasingly declines the portrayal of monotonous architecture of the Soviet urban modernity and aims its attention at the forbidden forms of the city - wooden houses, run-down neighbourhoods and wastelands (Fig. 3). Moreover, movies of this period aim to represent urban development that resulted in environmental degradation and social unsustainability as a result of negative effects of economic and social migrants coming from other parts of the Soviet Union. In movies, urban areas as 'contact zones' were filled with 'strangers' and rendered cultural attitude that was alienated and deprived of authentic identity [18], [22].

\section{From Marginalized Suburbs to Empty Spaces: Research Results}

The research consists of the analysis of 124 movies. The data for this study was collected using movie the database of the $\mathrm{Na}$ tional Film Centre of Latvia. These movies comprise the first illustrated series of microraions of Riga and were produced by state organizations. However, it is crucial to note that the producers were limited by heavy censorship imposed by the state. Therefore, movies form a comprehensive and representative sample of visualizations used in the official urban portrayal during the period between 1945 and 1991. Classification of reviewed movies is based on the theory of the model of five-stage construction of Daugavpils residential area by M. Gentile and Ö. Sjöberg, and 


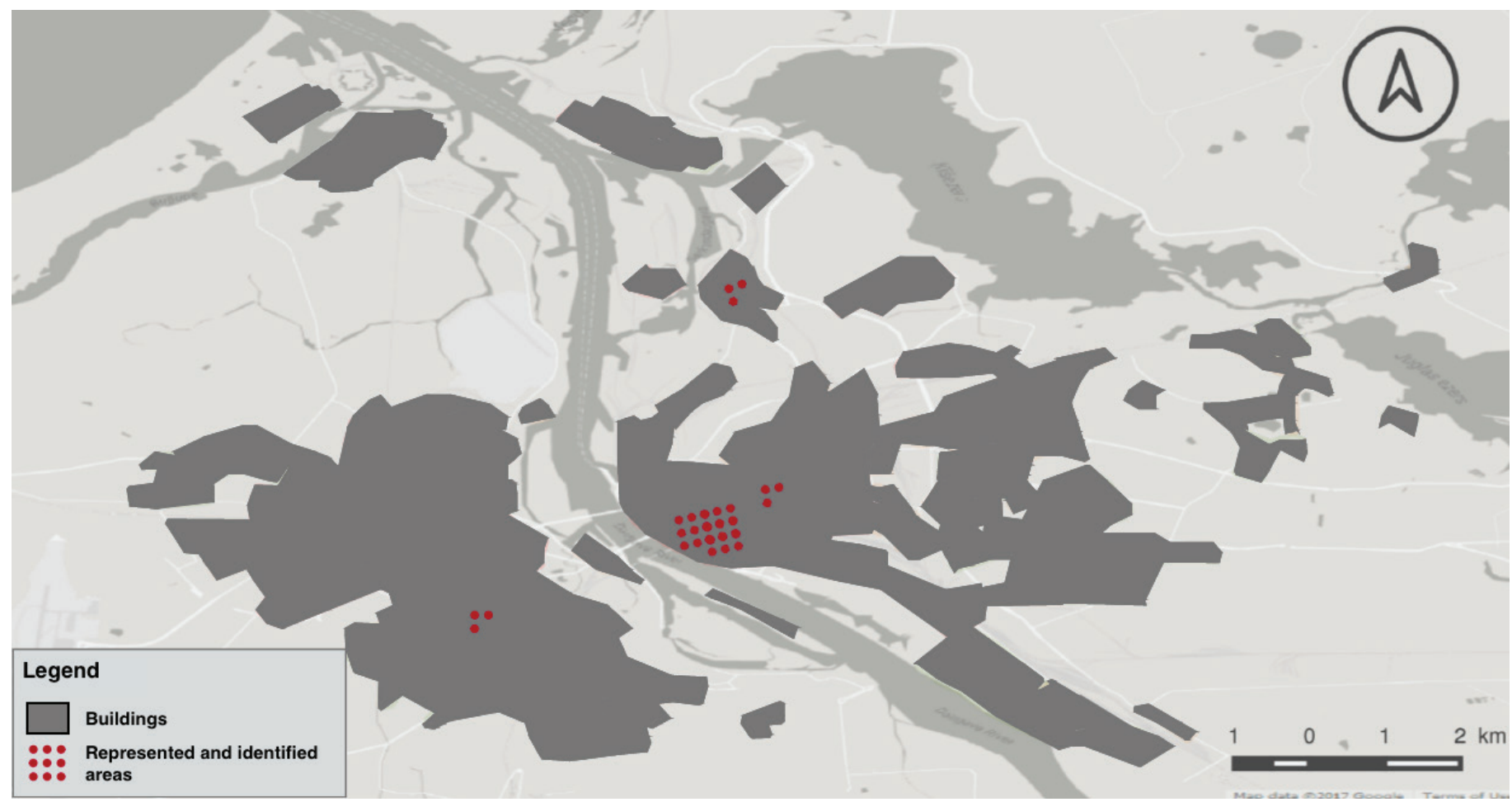

Fig. 4. Represented areas in reviewed movies from 1945 to 1957 [Picture: J. Matvejs].

on the analysis developed by A. R. Hazan, et al., where movies are coded into five-minute intervals.

In the first stage (1945-1957), part of existing state resources was distributed between the construction of socialism architecture, especially for military and internal security structures, as well as housing expropriation from the primary owners. These aspects also appear in 16 reviewed movies of this period (Fig. 4). Most of the movies are documentaries with descriptive spoken text, lack of technical approaches and static urban representation. The main themes of analysed films are new political system, industrial achievements, residential routine and acquisition of rural landscape. Moreover, no residential areas are depicted, instead most of the movies portray central parts of the city (series of documentary movie chronicles Padomju Latvija) and marginalized suburban areas with indigent wooden housing (Kā gulbji balti padebeši iet, P. Armands, 1957).

The second stage (1958-1964) is characterized by the expansion of industries. Consequently, better living spaces for proletariat are ensured, leading to the process of urbanization. From this period, 17 movies were analysed. The movies illustrate a varied city: Old Town, residential and industrial sites and transportation systems, with the main themes being the damages caused during World War II and a necessity to develop new residential areas. Microraioni are depicted in 9 movies, which are fragmented and contrasted with historical sites using montage technique (Akmens un šksembas, R. Kalniņš, 1965). The main focus is on the construction process and gender equalily, diverse and multicultural labour (Padomju Latvija Nr. 36, M. Šneiderovs, 1961); constructor of residential apartments is a communicator declaring utopian ideas, such as 'each brick makes people happier' in Padomju Latvija Nr. 31 (H. Šulatins, 1960).

In the third stage (1965-1971), the focus on the continuous expansion of prior enterprises in order to reduce deficiency of commodities and services. Accordingly, these conditions advanced effective construction of residential houses. The urban representation in 25 examined movies is more dynamic. During this period, the main character is a narrator of the city and there are additional filming methods, including scene merging and close-ups, which are used to highlight urban contrasts. Additionally, the movies of this period depict social clusters - markets, bus stops, railway station, courtyards or cafes opposed to mere urban portrayal in cinematography of the second stage. In 6 movies microraioni were identified, however residential areas were not recognized because of the lack of information about them and a very short time of demonstration. Nevertheless, in the movies of the third stage, microraioni already make an integral part of the city, where a courtyard and front entrance to the residential apartment blocks becomes a space of social conflict. Residential districts with advanced infrastructure are depicted in fiction movies (Meldru mežs, Ē. Lācis, 1971; Pēdējais blēdis, V. Mass, 1966), whereas in documentaries, five to nine-story apartments are only the background to the action (Padomju Latvja Nr. 16, B. Veldre, 1967).

The fourth period (1972-1985) introduces stagnation of industries. During this period, deficiency of commodities and lack of apartments gradually are defeated, however there is an increas- 


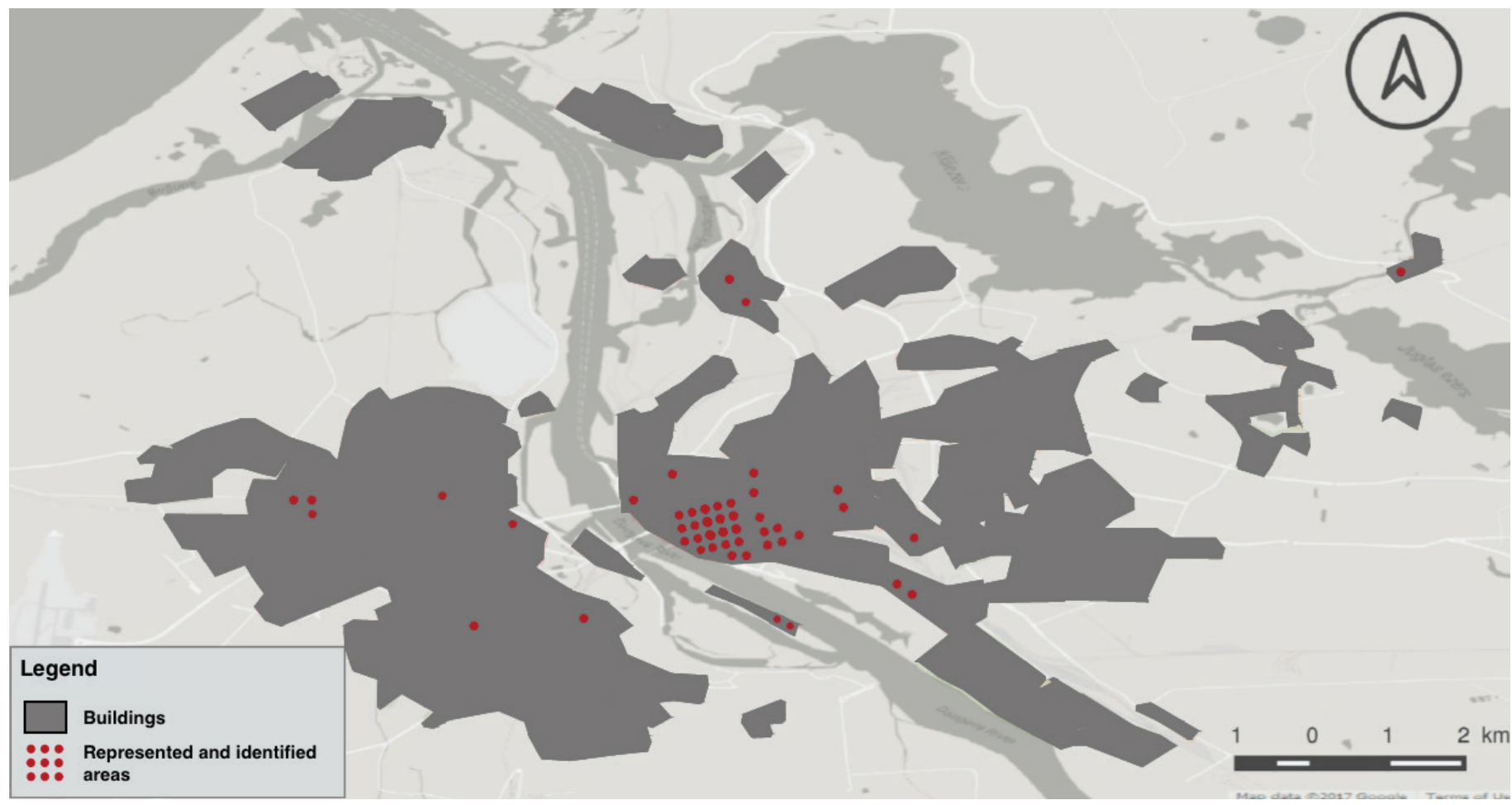

Fig. 5. Represented areas in reviewed movies from 1972 to 1985 [Picture: J. Matvejs].

ing concern about the quality of living. This period is characterised by the biggest number of reviewed movies -57 in total. Representation of the city is dichotomous: an individual is in the centre of photographical composition, however multiple activities and decisions of an individual are determined by urban setting. Movies depict various areas of the city, where all of them are considered to be social focal points (Fig. 5).

In 29 movies microraioni are portrayed as an integral part of the narrative. Considering all movies with residential districts from this period, five essential spatial representation groups could be classified. First, in most of the movies, residential areas are depicted as construction sites, where monotonous urban growth is described using factual information: migration numbers and population, number of constructed apartments each month, city plans and paper models (Pilsēta cilvēkiem, V. Krūmiņš, 1976). In several movies construction scenes are enriched with fragments of residents' workplaces representing various industries and authoritative spoken text. Secondly, microraioni, being a social environment, essentially illustrate courtyards full of youngsters where a janitor is a 'guard' (Dāvana pa telefonu, A. Brenčs, 1977). Social interaction is found also in recreational spaces, for example, in playgrounds or parks (Fig. 6 and 7). Thirdly, residential areas are also representative. Apartment buildings from reinforced concrete panels outline urban continuity and invent an image of a never-ending city in movies, especially by using areal filming techniques (Lielais dzintars, A. Brenčs, 1972; Atcerēties vai aizmirst, J. Streičs, 1981). Primarily only satisfied city residents are portrayed, nevertheless to please the author- ities, filmmakers use dogmatic approach by interviewing both progressive young people who 'admire new houses' and elder generation that is deviated due to 'being attached to traditional settlement' (Ābols upē, L. Leimanis, 1974).

Fourthly, interior is very important in this cinematic period. It is possible to compare the interior in Soviet movies with French philosopher Michel Foucault's social theory of panopticon where the main character is a watchman who rationally observes the external space (Laika prognoze augustam, J. Ločmele, 1983; Pēdèjā indulgence, A. Neretniece, 1985) (Fig. 8). Moreover, in most movies, interior is an intimate space and a place of safety (Aiz stikla durvim, O. Dunkers, 1978). Fifthly, residential districts are degraded by residents themselves. At the end of this stage, the movies depict living areas as incomplete and imperfect spaces with unfinished playgrounds, lack of facilities and untidiness (Vecā sètnieka piedzīvojumi, A. Burovs, 1985; Padomju Latvija Nr. 19, director unknown, 1980).

The fifth stage (1986-1991) is characterized by the shift from centrally planned to market economy. Political reforms and the national revival movement also changed the perception of residential space with emerging priorities of living standards and ecological solutions. All of the nine examined movies of this period suggest themes of social obstacles and depict mundane fallibility. Despite the fact that the reviewed films depict various urban areas, 6 of them contain microraioni. Residential districts are represented as socially empty space. These areas are the background for protagonist's situational and purposeless movement through the city (Rīga 1989, RTU mācībspēks). In this period 


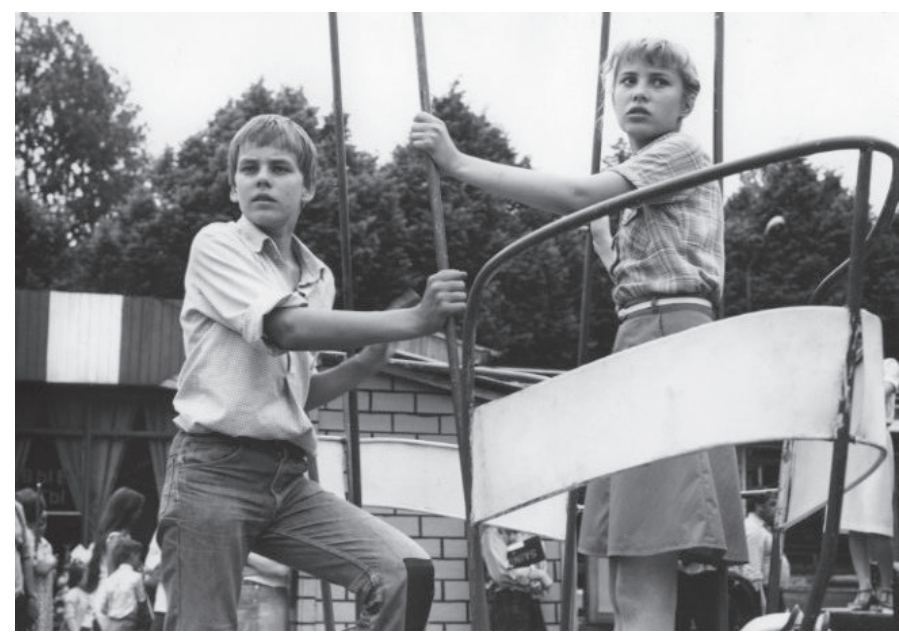

Fig. 6. Courtyard as a space of activity and recreation in movie Laika prognoze augustam (1983) [31]

filmmakers also disregard formal guidelines by looking for ecological solutions (Padomju Latvija Nr. 14, I. Jaunzems, 1988) and portraying proscribed city parts: single-family detached housing, incomplete apartments and discoloured urban structure (Par mīlestību pašreiz nerunāsim, V. Brasla, 1988).

\section{Conclusion}

Even though this study does not give a clear answer about Riga being a cinematic city according to Guliana Bruno's classification of photogenic places [2], yet this research elucidates the manner and practices of representing living areas in the Soviet period. This study has found that microraioni are frequently portrayed in the movies of the Soviet period and thus form an essential part of Soviet urban structure. Residential areas and the Old Town, transportation systems and industrial sites are an integral part of the Soviet urban perception frequently represented in documentaries, fiction movies and animation movies.

From the mid-1940s until the end of the 1950s, no residential areas are represented in cinema. At the same time, filmmakers follow the official political ideas by using rhetoric about preliminary plans of industrialization and sharing information about progress in construction of residential areas, therefor idealizing them. Moreover, vast representation of the Old Town in cinematography of this period 'westernized' the Soviet space.

Substantial representation of microraioni starts at the beginning of the 1960s. Similarly, in this period political ideology regulated cinematography. From the end of the 1960s to the beginning of the 1980s, residential areas make an integral part of visually represented space. In addition to the portrayal of concrete residential blocks, the lights are shed on public services and infrastructure around microraioni that are rather utopian and do not illustrate actual urban accomplishments. Starting with the mid-1980s, representation of microraioni decreased due to the intensive search for ecological solutions and opportunities to im-

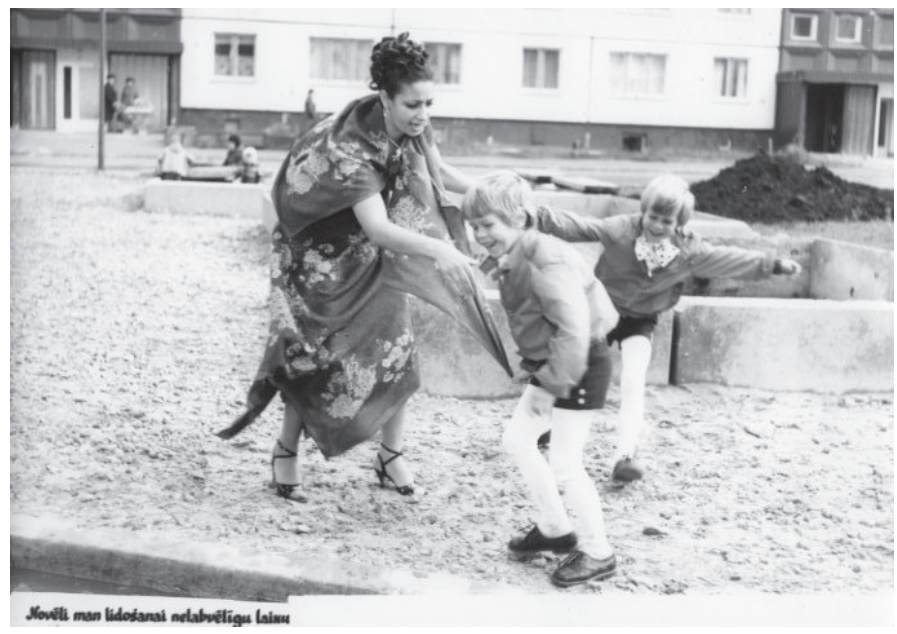

Fig. 7. Courtyard as a space of activity and recreation in movie Novēli man lidojumam nelabvēlīgu laiku (1980) [31]

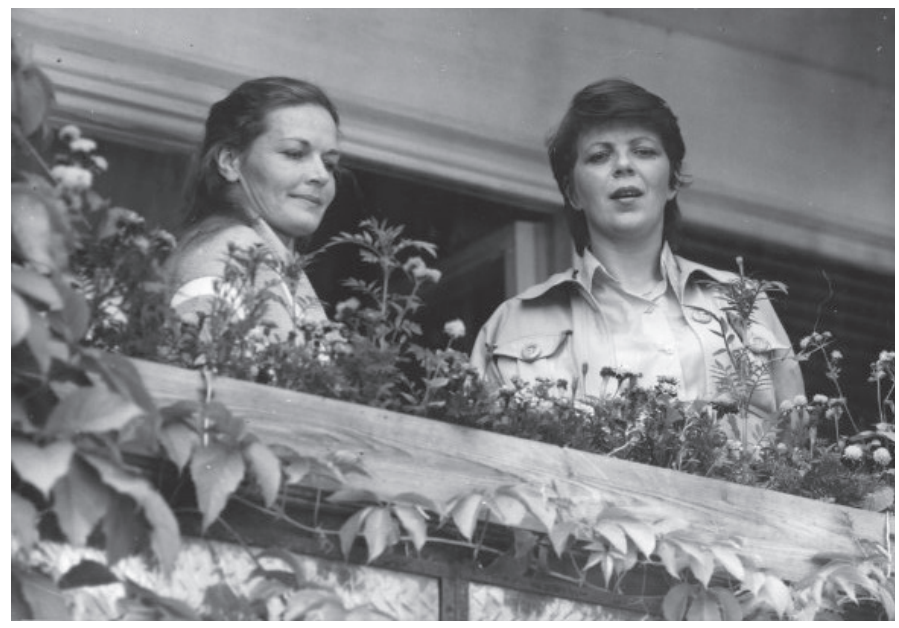

Fig. 8. Balcony as a panopticon, where Nina and Lilga rationally observe the courtyard in fiction movie Atceréties vai aizmirst (1981) [31].

prove living standards. In various movies, residential areas are neglected. Moreover, during this period, filmmakers emphasise the priority of mental over physical environment of microraioni by filming conversations with locals, depicting imperfections and disagreeing with the official ideas.

Although Soviet movies have not accomplished their primary goal of restricting perception of urban space and the fact that residential districts have experienced numerous improvements in the recent years, it can be stated that the Soviet cinema is a crucial evidence that illustrates technological achievements both in urban planning and cinematography, qualities and expectations of society of that particular period. 


\section{REFERENCES}

1. Alexandrova, A., Hamilton, E., Kuznetsova, P. Housing and Public ser vices in a Medium-Sized Russian City : Case study of Tomsk. Eurasian Geography \& Economics Vol. 45, Issue 2, 2004, pp. 114-133. http://dx.doi. org $/ 10.2747 / 1538-7216.45 .2 .114$

2. Bruno, G. City Views: The Voyage of Film Images. The Cinematic City [D.B. Clarke, ed.]. London: Routledge, 1997, p. 47.

3. Bunkše, E.V. The Role of a Human Environment in Soviet Urban Planning. Geographical Review, Vol. 69, Issue 4, 1979, pp. 379-394.

4. Creswell, T., Dixon, D. Engaging Film : Geographies of Mobility and Identity. Lanham: Rowman \& Littlefield, 2002, pp. 2-3.

5. French, R.A. Plans, pragmatism and people: the legacy of Soviet planning for today's cities. London: UCL Press, 1995, p. 62-152.

6. Gentile, M., Sjöberg, Ö. Intra-urban Landscapes of Priority : The Soviet Legacy. Europe-Asia Studies, Vol. 58, Issue 5, 2006, pp. 701-729. https:// doi.org/10.1080/09668130600731268

7. Gentile, M., Sjöberg, Ö. Space of Priority : The Geography of Soviet Housing Construction in Daugavpils, Latvia. Annals of Association of American Geographers, Vol. 100, Issue 1, 2010, pp. 112-136. https://doi. org/10.1080/00045600903378994

8. Grava, S. The urban heritage of the Soviet regime: the case of Riga Latvia. Journal of the American Planning Association, Vol. 59, Issue 1, 2007 pp. 9-22. https://doi.org/10.1080/01944369308975842

9. Hall, T. The camera never lies? Photographic research methods in human geography. Journal of Geography in Higher Education. Vol. 33, Issue 3, 2009, pp. 453-462. https://doi.org/10.1080/03098260902734992

10. Hay, J. Piecing together what remains of the cinematic city. The Cinematic City [D. B. Clark, ed.]. London: Routledge, 1997, pp. 211-214.

11. Hazan, A.R., Lipton, H.L., Glantz, S.A. Popular films do not reflect current tabacco use. American Journal of Public Health, 1994, No. 84 pp. $998-1000$

12. Kaganovsky, L. Postmemory, Counter-memory : Soviet Cinema of the 1960s. The Socialist Sixties · Crossing Borders in the Second World [A. Gorsuch, D. Koenker, ed.]. Indiana: Indiana University Press, 2013, pp. 235-243.

13. Kraftl, P., Horton, J. Urban representation/imagination. International Encyclopaedia of Human Geography [R. Kitchen, N. Thrift, ed.]. Oxford: Elsevier Science, 2009, pp. 96-97.

14. Lukinbeal, C., Zimmermann, S. The Geography of Cinema - A Cinematic World. Stuttgart: Franz Steiner Verlag GmbH, 2008, p. 15.

15. Mazierska, E. The Politics of Space in Polish Communist Cinema. Via Transversa: Lost Cinema of the Former Eastern Bloc [E. Näripea, A. Trossek, ed.]. Spec. issue of Place and Location: Studies in Environmental Aesthetics and Semiotics, 2008, pp. 229-245.

16. Mazierska, E. Squeezing Space, Releasing Space: Spatial Research in the Study of Eastern European Cinema. Cinema, State Socialism and Society in the Soviet Union and Eastern Europe, 1917-1989: Re-visions [S. Bahun, J. Haynes, ed.]. London: Routledge, 2014, p. 9.

17. Mehilli, E. The Socialist Design : Urban Dilemmas in Postwar Europe and the Soviet Union. Kritika: Explorations in Russian and Eurasian History. Vol. 13, Issue 3, 2012, pp. 635-665.

18. Näripea, E. HOME and AWAY: Urban Representations in 1980s Soviet Estonian Cinema. Spec. issue of Place and Location: Studies in Environmental Aesthetics and Semiotics, 2003, pp. 405-431.

19. Näripea, E. Medieval socialist realism: Representations of Tallinn Old Town in Soviet Estonian feature films, 1969-1972. Spec. issue of Place and Location: Studies in Environmental Aesthetics and Semiotics IV, 2004 pp. 121-144.

20. Näripea, E. National Space, (Trans)National Cinema. Estonian Film in the 1960s. A Companion to Eastern European Cinema [A. Imre ed.]. Oxford: Wiley-Blackwell, 2012, pp. 244-255.

21. Novikova, I. Images of City and Europeanness in Soviet Cinema. Film Architecture, Urban Space and The Moving Image [J. Hallam, R. Kronenburg, L. Roberts, R. Koeck, ed.]. Liverpool: University of Liverpool, 2008, pp. 193-197.

22. Novikova, I. The Cinematic City and Itineraries in Riga, Tallinn and Vilnius. Urban Semiotics : The City as a Cultural-Historical Phenomena [I. Pilshchikov, ed.]. Tallinn: Tallinn University Press, 2015, pp. 119-139.

23. Prokhorov, A. Springtime for Soviet Cinema. Re/Viewing the 1960s. Pittsburgh: Russian Film Symposium, 2001, pp. 119-142.

24. Ronneberger, K., Schöllhammer, G. Monumental and Minimal Space: Soviet Modernism in Architecture and Urban Planning. An introduction [online]. The Thread [cited 15.09.2017.]. http://www.red-thread.org/en/ article. $a s p ? \mathrm{a}=34$

25. Rose, G. Teaching visualised geographies : towards a methodology for the interpretation of visual materials. Journal of Geography in Higher Education. Vol. 20, Issue 3, 1996, pp. 281-294. https://doi. org/10.1080/03098269608709373

26. Rose, G. Visual methodologies: An introduction to the interpretation of visual materials. London: Sage, 2007, pp. 32-46.

27. Ruoppila, S. Processes of Residential Differentiation in Socialist Cities: Literature Review on the cases of Budapest, Prague, Tallinn and Warsaw. European Journal of Spatial Development. No. 9, 2004, pp. 3-19.
28. Sanders, R. Developing geographers through photography: enlarging concepts. Journal of Geography in Higher Education. Vol. 3, Issue 1, 2007 pp. 181-195. https://doi.org/10.1080/03098260601033118

29. Sidaway, J. D. Photography as geographical fieldwork. Journal of Geography in Higher Education. Vol. 26, No. 1, 2002, pp. 95-103. https:// doi org/10.1080/03098260120110395

30. Smith, R. G. Jean Baudrillard : From Hyperreality to Disappearance. Edinburgh: Edinburgh University Press, 2015, pp. 32-33.

31. Photo by Riga Film Museum Archive.

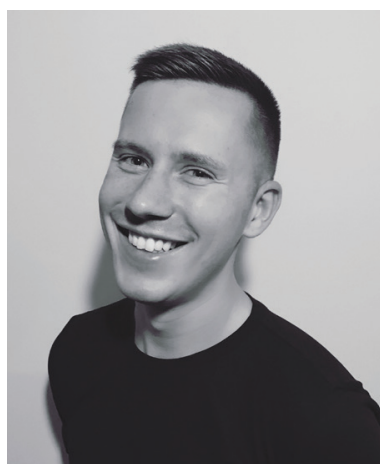

Jānis Matvejs (b. Riga, 1991) received the degree of Bachelor of Arts from the Latvian Academy of Culture in 2014 and the degree of Master of Geography from the University of Latvia in 2016. Since 2016, he has been a Ph. D. student with the University of Latvia The topic of his thesis is "Architecture and its representation in Soviet cinema: the case of Riga". He participated in several international conferences in geography, the latest being "Nordic Geographers' Meeting 2017” at Stockholm University. His current research interests are urban landscape, city and suburban space, cinematography, cultural geography, visual methods in geographical researche.

\section{Contact Data}

\section{Jānis Matvejs}

Faculty of Geography and Earth Sciences

University of Latvia

Address: 1 Jelgavas St., Riga, LV-1004

Phone: +371 29878918

E-mail: janis.matvejs@gmail.com 